\title{
SIBIU CAPITAL OF CULTURE STATUS IMPACT ON THE CREATIVE ECONOMY
}

DOI: http://dx.doi.org/10.18509/GBP.2020.40

UDC: 332.122.055.2:711.45(498)

\author{
Marian Marin ${ }^{1,2}$ \\ Radu-Daniel Pintiliii ${ }^{1,2}$ \\ Andreea Karina Gruia ${ }^{1,2}$ \\ Alexandra Grecu1,2 \\ Arina Mărunțelu1,2 \\ ${ }^{1}$ University of Bucharest-Research Center for Integrated \\ Analysis and Territorial Management; Bucharest, Romania \\ ${ }^{2}$ Faculty of Geography, University of Bucharest, Bucharest, Romania
}

\begin{abstract}
Obtaining the title of European Capital of Culture in 2007 represents for city of Sibiu an important economic achievement. The entire process began a few years before, and it was consisting in developing the creative economy alongside other economic aspects.

The entire developing process was first based on performing arts and the related activities. For this, all major actors, local administration, governmental agencies and private stakeholders proposed and developed programs for sustaining creative economy. New financing lines, from Romanian government or from EU were used, new partnerships were initiated between Romanian firms and institutions and firms from abroad.

As our analysis had underlined, using NACE cods (number and activity domain), the period before 2007, was characterized by an increasing number of private initiatives in the creative economy. Most part of them were related to the performing arts, marketing and architecture. This situation can be sustained with arguments, such as The International Theatre Festival, architectural heritage, dating from saxon period, both contributing to the Sibiu multicultural context. From this initial activity, the creative economy became diverse, by including other approaches (publicity, arts production, printing, digital technology etc.).

After the 2007 moment, Sibiu creative economy became more powerful, the city, and the adjacent zone, being involved in more diverse programs belonging to the creative economy. Movie production, crafts, design and fashion design (as examples) as activities were implied into promoting cultural particularities and specificities at the local and regional level. Local, national and international economic actors have contributed to the Sibiu European cultural hub status. More than that, a lot of multiplicity effects had appeared, contributing in this way to local and regional economy diversification.
\end{abstract}

Keywords: creative, Sibiu, culture capital, economy

\section{INTRODUCTION}

Creativity is assumed to be a transferable ability, and the development of population creativity will support innovation within the economic sectors [1]. Moreover, culture can be considered as a source of innovation [2], a provider of economic independence [3], generated by the entrepreneurial spirit of the creative population [4]. Following the public consultation, the European Commission in 2010 mentioned that "cultural and creative 
industries (...) contribute to the competitiveness and social cohesion of our cities and regions". From the perspective of the role of the creative economy in the development process, the evolution of economic models must be considered. Thus, the conventional economic development model emphasizes attracting firms and activities from abroad, with policies having cost-based incentives, minimizing regulations and marketing strategies [5], [6]. The creative city model is based on attracting talent, through policies on increasing the quality of spaces and developing facilities on art and culture [7], [8], [9]. The model of the cultural industries concerns the agglomeration processes, the specialization of the companies and the links between them. To achieve these goals, the policies undertaken support a minimization of the risks and costs of transactions, and an improvement of information and partnerships [10], [11], [12], [13],[14], [15].

About the model of cultural occupations, they focus on the characteristics and needs of artists and associated occupations. This is achieved through policies aimed at artistic centers with accessible spaces, by preparing and stimulating social and business networks [16], [17]. The cultural planning model brings into question the informal arts / culture and the development of communities, these being achieved by identifying the elements that result in the empowerment and consolidation of these communities [18]. Case studies reveal that the creative city model dominates contemporary economic development and invariably facilitates the emergence of neo-liberal development schemes [19].

For European cities that are candidates or not for the title of Capital of European Culture, the development strategy is also based on the inclusion of a key element, such as the organization of one or more events. The status of European cultural capital undoubtedly contributes to the resizing of the city's image and economy. Stimulating physical development is a triggering factor along with generating economic, social and cultural benefits. For cultural events or urban development policies that include cultural activities, the greatest challenge is to achieve a balance between the incomes achieved in all areas and to generate sustainable development [20].

One can speak at this time of the existence of a new trend in terms of cultural tourism, a trend provided by the concept of Capital of European Culture. In addition to be an asset for this type of tourism, it can influence and promote cultural productions, promote a new perspective on the city but also facilitate partnerships. Lately, culture, through cultural products, has become a relevant factor in marketing the tourist destination [21]. Sibiu as the Capital of European Culture in 2007 managed to impose several international cultural events (International Theater Festival, Jazz Festival) that functioned as vectors of urban marketing. They were added a contrasting urban landscape (the old city center antithetical to the newer areas), also reinvigorated and reinvented from the perspective of supporting artistic productions. Meanwhile, the cultural offer of the city has diversified, succeeding in creating Sibiu a tourist destination throughout the year.

Event tourism, as a particular approach to cultural tourism, has undergone a significant development in recent years. Event-type productions have become a solution of the problems related to the differentiation of the tourist product, seasonality and increasing competitiveness within the tourism market. Cultural events have become means of economic revitalization, of urban transformation, of repositioning of the tourist destination, of generating investments and implicitly of income [22], [23]. The present case highlights this progress both vertically and horizontally, through an economic diversification, especially in the creative field, in parallel with an infrastructure development. 
Cities represent the space for a continuous flow of cultural events that ultimately lead to their festival [24].

The analytical framework that highlighted the economic impact of the events associated with the Capital of European Culture [25] in the context of creative economies, has led to the development of models. According to the ACCES agenda, the six relevant aspects refer to: arts - the benefits for the artistic community; culture, through the role of festivals in the creation, promotion and conservation of heritage; the community, and to what extent the artistic productions satisfy its business needs; economy, viewed through the net benefit of festivals; society, related to the social benefits of cultural events and productions; stakeholders, and their role in supporting cultural festivals and productions.

\section{METHODOLOGY}

As a study area, one of the cities of Romania, that gained the European Capital of culture in 2007, Sibiu is chosen. Its geographical position is in the center of the country, located $275 \mathrm{~km}$ far away from Bucharest and according to the National Census in 2011, it counted about 147,245 inhabitants. In order to see the impact of that status in the creative economies, a complex database, containing the number of companies, the employees, the turnover and the profit has been used. The detail level of the database is at 4 digit NACE code and provide useful information about the Creative field. Being a complex one, the data based has been focused on the main branches of them.

\section{RESULTS}

The analytical context regarding the evolution of employees in the creative sector, shows a positive one overall, with small fluctuating episodes. Until 2007, except for a spectacular growth in the field of health and social assistance, a fact due to a population influx generated by the period preceding the events related to the capital status of the European culture, the other components of the creative field had an increasing evolution. However, in the same sense, we note the increase of activities in the field of high-techknowledge. The year 2007, when the city of Sibiu becomes the Capital of European Culture, finds the creative field on an upward trend (education is growing significantly). After 2007 we can talk about a decline in the knowledge-high-tech, education, communications and information sectors, largely generated by the crisis that started in 2008. This period was marked by a migration of the labor force, fact reflected by the decrease of the education sector. Interesting is the evolution in the period after the role of the European cultural capital, noting a sustained growth on all levels, especially in the area of cultural activities. One of the strongest arguments is represented by the International Theater Festival, which manages to establish itself as a world-class event, making a decisive contribution to the creation of an image of a global cultural center, the city of Sibiu (Figure 1). 


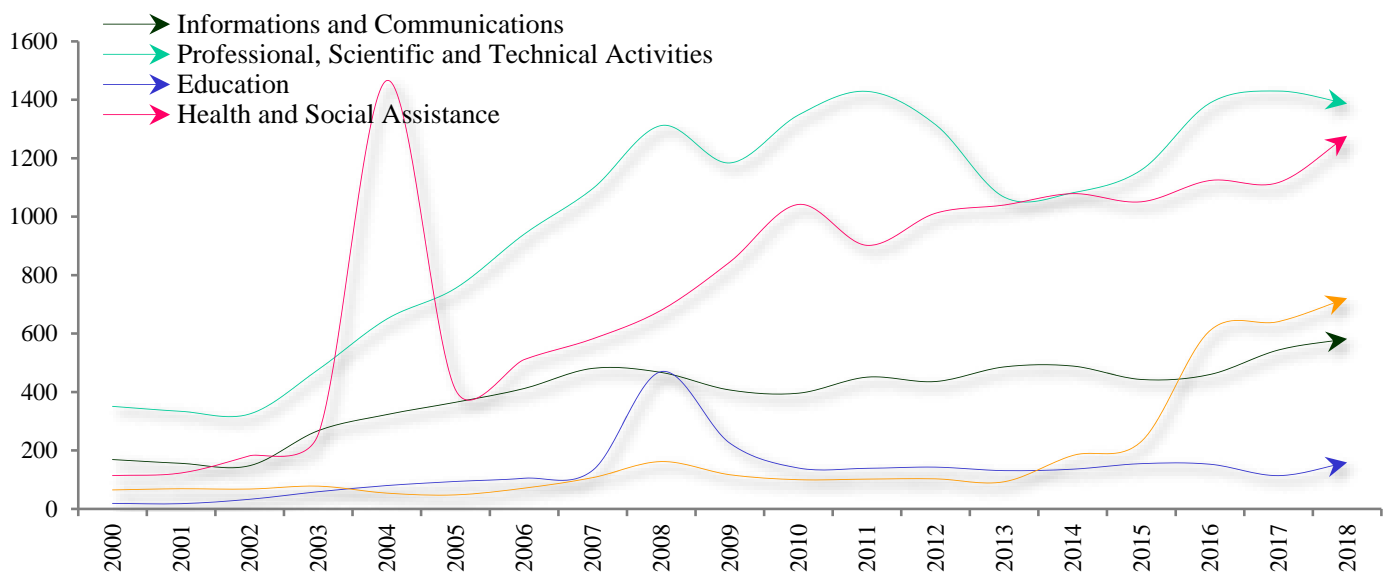

Figure 1. Evolution of employees in the main creative sector in Sibiu Source: Project UB 1423

Regarding the number of companies in the main creative field a continuous constant growth of all activities could be seen (Figure 2). An exception for the high-techknowledge level, with a more accelerated growth. The situation is due to the extremely tender urban-cultural context, the level of tolerance and cosmopolitanism and not least to the natural context. The capital of image gained and the transformations that occurred at the level of the urban structure after winning the title of Capital of European Culture, made Sibiu an extremely attractive city for companies in the creative field.

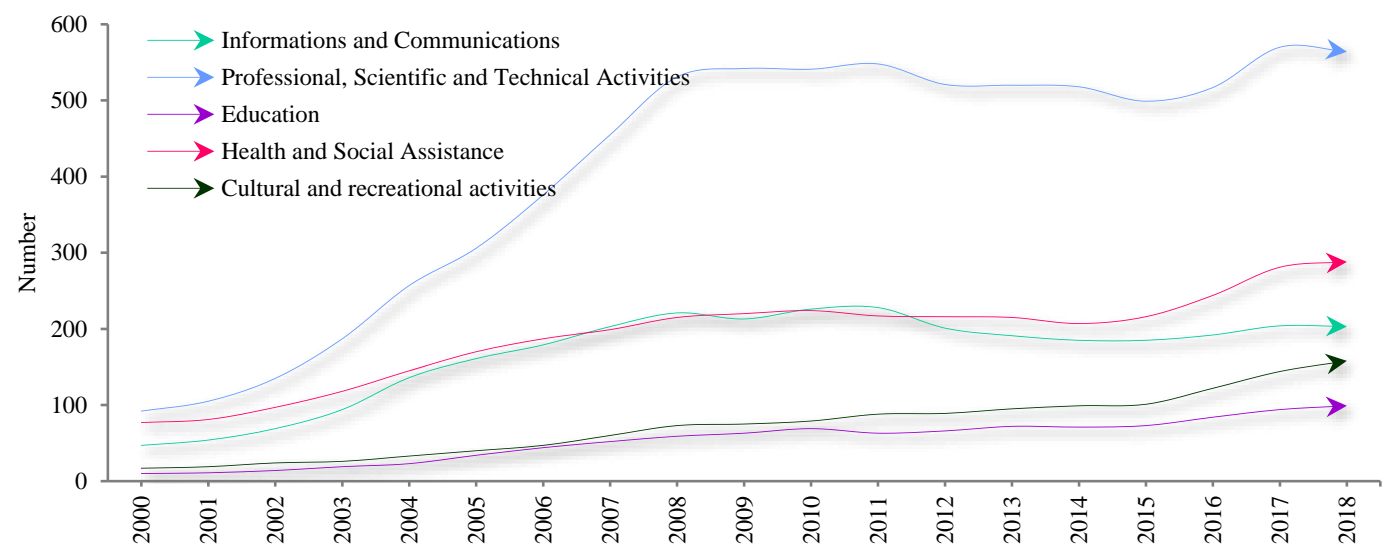

Figure 2. Evolution of companies in the main creative sector in Sibiu Source: Project UB 1423

As a percentage in the creative field, at the level of 2000 one can see a similarity between the activities of health and social assistance and those in the field of knowledge-hightech, low percentage in terms of education and cultural activities, because in the middle area to situate the activities in communications and information (Figure 3). This moment represents the beginning of a period of economic reorganization in the city of Sibiu.

At the level of 2018, there is an increase in the percentage of activities in the field of knowledge-high-tech (largely due to the cultural, natural advantages that the city of Sibiu offers, and which are targeted by companies in this field - money and pleasant places). 
To this is added education and cultural activities, the latter driven by the role of cultural HUB that Sibiu assumed (Figure 4).

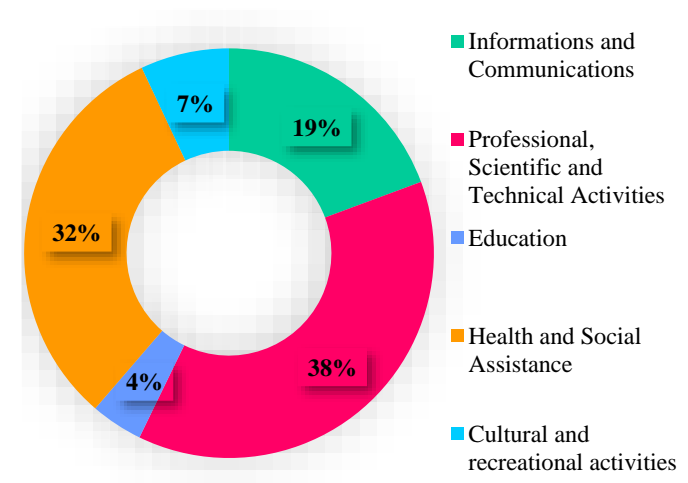

Figure 3. Structure of companies in the main creative sector in Sibiu (2000)

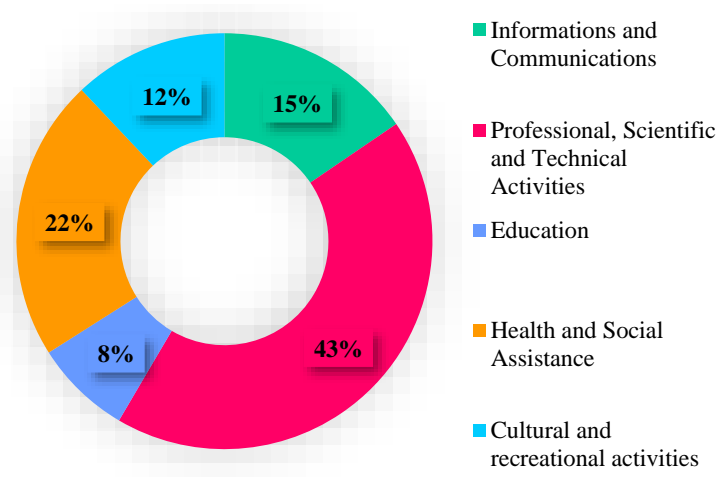

Figure 4. Structure of companies in the main creative sector in Sibiu (2018)

Source: Project UB 1423

Benefiting from the economic legacy that the city of Sibiu had but also from the processes of economic conversion and reorganization, the high-tech-technologies sector manages to hold the highest percentage in terms of labor force (Figure 5). On the immediate next position is the field of information and communications, Sibiu having an advantageous position in this regard. The small percentage in terms of education can also be explained by the poor representation of private initiative in this sector.

Unlike the situation in 2000, in terms of cultural activities, they almost doubled their percentages as a result of the entire context generated by the status of cultural capital (Figure 6). There is also a significant increase (almost double) of the number of employees without health and social assistance largely due to the development of the private component.

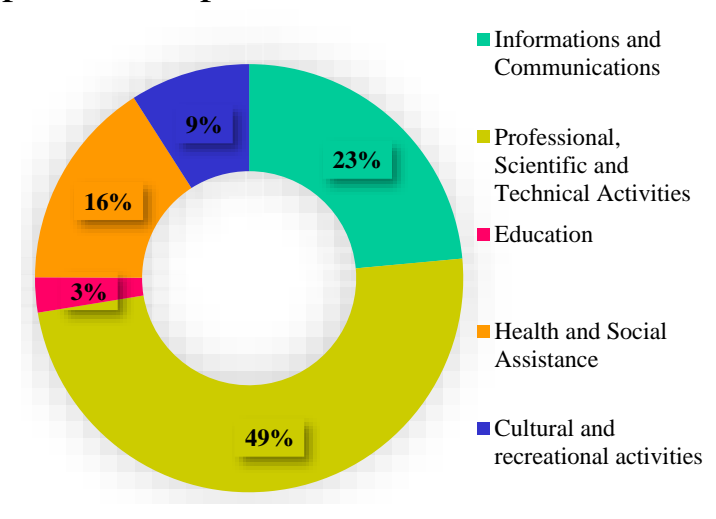

Figure 5. Structure of employees in the main creative sector in Sibiu (2000)

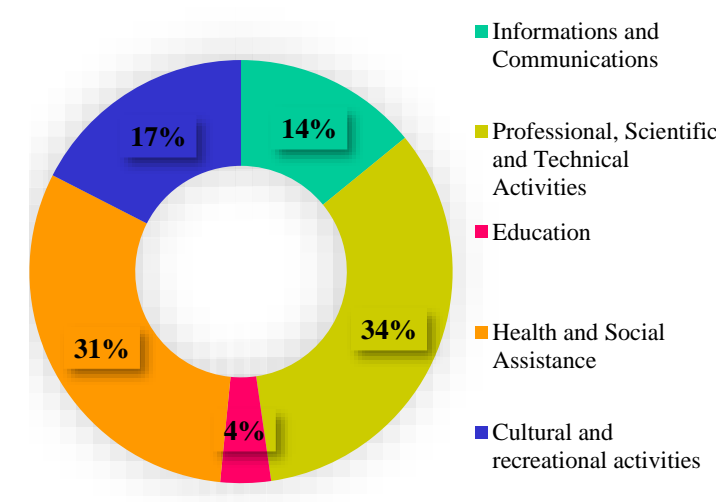

Figure 6. Structure of employees in the main creative sector in Sibiu (2018) Source: Project UB 1423

The number of companies in the creative field (Figure 7), has grown steadily even though there have been regressive milestones, associated with the repositioning generated by the economic crisis of 2008-2010. In terms of turnover (Figure 8), the general trend has been growing. This was accentuated after 2007, as a result of the increasing influence of the creative field for the whole economy of Sibiu, and especially after 2015, when Sibiu was 
detached and established as an important cultural center. Although on an upward trend, the profit of the creative field (Figure 10) is experiencing a spectacular evolution towards the end of the analyzed period (2015-2018).

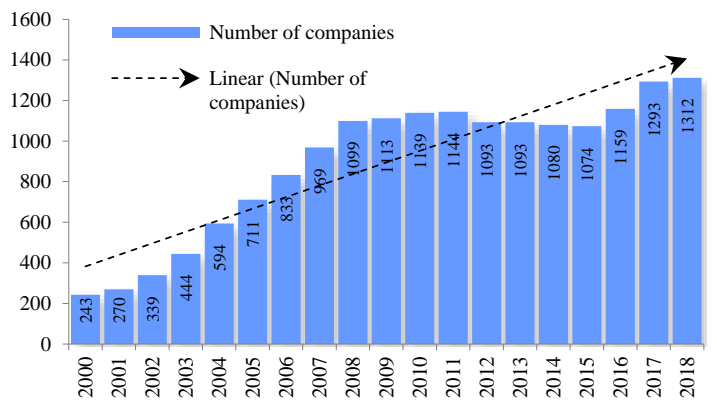

Figure 7. Evolution of number of companies in Sibiu

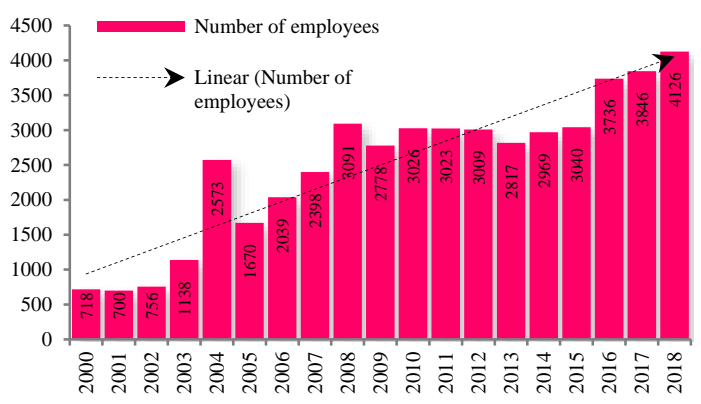

Figure 9. Evolution of number of employees in Sibiu

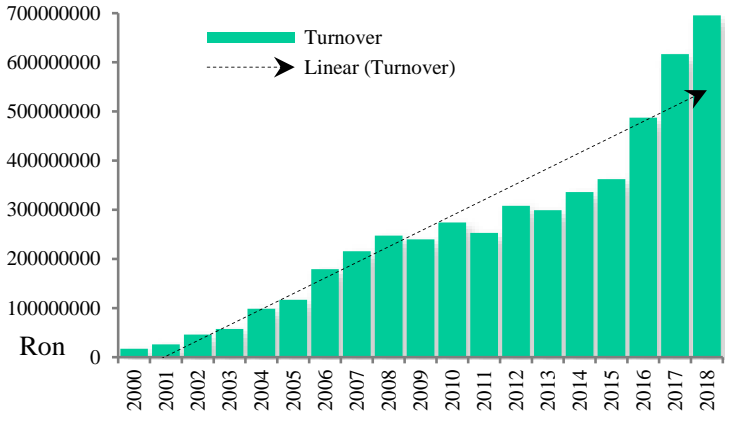

Figure 8. Evolution of turnover in Sibiu

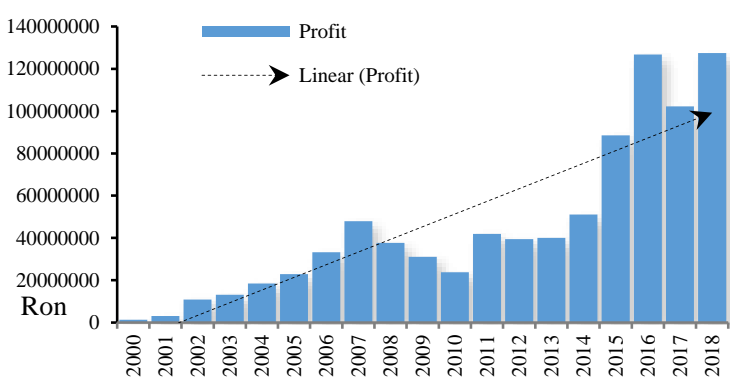

Figure 10. Evolution of profit in Sibiu

Source: Project UB 1423

\section{CONCLUSIONS}

The adaptive capacity of the territorial system is also reflected in the increasing trend of number of employees in the creative field [26], [27]. One can easily identify the impact that the role of European cultural capital had between 2008-2012, even if it overlaps with the crisis period. It is thus proven that the creative economy together with the local / regional / national governance can be shock mitigating factors.

The evolution of profit explains this situation by the economic repositioning of the urban structure after the economic crisis, and its orientation towards the creative economy.

\section{REFERENCES}

[1] Böhm S. \& Land C. No measure for culture? Value in the new economy. Capital and class, vol.97, pp 75-98, 2009.

[2] Lazzeretti L. Culture, creativity and local economic development. In: P. Cooke, 2007.

[3] Acs Z., Bosma N. \& Sternberg R. The entrepreneurial advantage of world cities. Jena: Friedrich Schiller University, 2008.

[4] Florida R. The rise of the creative class, New York: Basic Books, 2004. 
[5] North D. Location theory and regional economic growth, Journal of Political Economy, vol 63, 1955.

[6] Blakely E. \& Green Leigh N. Planning local economic development: theory and practice. Fourth edition, Sage, Thousand Oaks, CA, 2010.

[7] Landry C. The creative city: a toolkit for urban innovators, Comedia, London, 2000.

[8] Florida R. The rise of the creative class. Basic Books, New York, 2002.

[9] Cooke P. \& Schwartz D. Creative regions: technology, culture and knowledge entrepreneurship. London: Routledge, pp 69-196, 2007.

[10] Florida R. The rise of the creative class. Basic Books, New York, 2002.

[11] Hesmondhalgh D. The cultural industries. Second edition, Sage, London, 2007.

[12] Pratt A. The cultural industries production system: a case study of employment change in Britain, 1984-1991, Environment and Planning, vol. 29, 1997.

[13] Pratt A. Cultural industries and public policy: an oxymoron?, International Journal of Cultural Policy, vol 11, 2005.

[14] Scott A. The cultural economy of cities: essays on the geography of image-producing industries, Sage, London, 2000.

[15] Scott A. Cultural-products industries and urban economic development: prospects for growth and market contestation in global context, Urban Affairs Review, vol. 39, 2004.

[16] Markusen A. Targeting occupations in regional and community economic development, Journal of the American Planning Association, vol. 70, 2004.

[17] Markusen A. Urban development and the politics of a creative class: evidence from the study of artists. Environment and Planning, vol. 38, 2006.

[18] Grodach C. Cultural Economy Planning in Creative Cities: Discourse and Practice. International Journal of Urban and Regional Research, 2012.

[19] Peck J. Struggling with the creative class, International Journal of Urban and Regional Research, vol 29, 2005.

[20] Yi-De Liu. Cultural Event and Urban Regeneration: Lessons from Liverpool as the 2008, European Capital of Culture. European Review, vol. 24, pp 159-176, 2016.

[21] Yi-De Liu. Cultural Events and Cultural Tourism Development: Lessons from the European Capitals of Culture. European Planning Studies, vol. 22, pp498-514, 2014.

[22] Smith M. K. Issues in Cultural Tourism Studies (London: Routledge), 2003.

[23] Quinn B. Festivals, events and tourism, in: T. Jamal \& M. Robinson (Eds) The SAGE Handbook of Tourism Studies, pp 483-503, 2009.

[24] Richards G. \& Wilson J. The impact of cultural events on city image: Rotterdam, cultural capital of Europe 2001, Urban Studies, vol. 41, pp 1931-1951, 2004.

[25] Carlsen J., Ali-Knight J. \& Robertson M. Access: A research agenda for Edinburgh festivals, Event Management, vol. 11, pp 3-11, 2007.

[26] Pintilii R.D., Peptenatu D., Draghici C., Irina S., Stoian R.D. Structural Changes in The Entrepreneurial Profile of The Creative Industries in Romania, 2nd Global Conference on Business, Economics, Management and Tourism, Czech Republic, 2015, pp1147-1151;

[27] Pintilii R.D., Peptenatu D., Ciobotaru A-M., Toma S., Grigore A.M., C.-C. Drăghici, Dobrea R.-C., Simion A.G., Andronache I., Teodorescu C., Diaconu D.C., Creative Economies in Romania-Spatial Projections and Trends, Bulletin of Geography. Socio-economic Series, vol. 37, 95-108, 2017. 